\title{
Assessment of pregnant, primiparous and postpartum women's knowledge about dental caries
}

\author{
Avaliação do conhecimento de gestantes e puérperas primíparas e multíparas sobre cárie dentária
}

Andreza Cristina de Lima Targino MASSONI

Rosaney Barbosa PEREIRA²

Danúbia Roberta Medeiros NÓBREGA²

Luciana Ellen Dantas COSTA ${ }^{3}$

Jocianelle Maria Felix de Alencar FERNANDES ${ }^{4}$

Aronita ROSENBLATT ${ }^{4}$

\section{ABSTRACT}

\section{Objective}

To make a comparative assessment of primiparous and multiparous mothers' knowledge about dental caries, access to information and use of dental services during pregnancy.

\section{Methods}

This cross-sectional, quantitative study was conducted in a Reference Maternity center for the Seridó region of Rio Grande do Norte, with 100 women aged between 12 and 45 years, who answered a structured questionnaire.

\section{Results}

The majority of patients received information on oral health (70\%) $(p=0.24)$, but only $42 \%$ sought dental care during pregnancy $(p=0.45)$. The interviewees considered caries (80\%) ( $p=0.80)$, a communicable disease $(64 \%)(p=0.29)$ arising due to inadequate brushing (60\%) ( $p=0.37)$. Pregnant women considered a brush with soft bristles and small head appropriate $(59 \%)(p=0.83)$ and reported that the amount of toothpaste should extend over the entire brush (46\%) ( $p=0.04)$. "Brush your teeth" was the most cited response (70.9\%) in their speeches on caries prevention.

\section{Conclusions}

In general the mothers in this study presented similar characteristics as regards knowledge about dental caries, access to information and use of dental services, however, there was significant difference between the groups for the variable quantity of toothpaste used. Nevertheless, some aspects such as the multifactorial etiology of dental caries, biofilm, use of dentifrices, and seeking information and dental services from the perspective or oral health prevention and promotion still need to be worked on among these mothers. These are simple aspects that must be considered in daily care by both pregnant and multiparous women

Indexing terms: Dental caries. Knowledge. Pregnant women.

\section{RESUMO}

\section{Objetivo}

Avaliar, comparativamente, o conhecimento de mães primíparas e multíparas, sobre cárie dentária, acesso à informação e a busca por serviço odontológico durante a gestação.

\section{Método}

Este estudo transversal e quantitativo foi realizado em uma Maternidade de Referência para a região do Seridó do Rio Grande do Norte, com 100 gestantes, entre 12 e 45 anos, que responderam ao formulário estruturado.

\section{Resultados}

A maioria das gestantes recebeu informações sobre saúde bucal $(70 \%)(p=0,24)$, mas apenas $42 \%$ buscaram atendimento odontológico durante a gravidez $(p=0,45)$. As entrevistadas consideraram a cárie uma doença $(80 \%)(p=0,80)$, transmissível $(64 \%)(p=0,29)$ e que surge devido à escovação inadequada $(60 \%)(p=0,37)$. As gestantes consideraram apropriada a escova com cerdas macias e cabeça pequena $(59 \%)$ $(p=0,83)$ e afirmaram que a quantidade de creme dental deve estender-se sobre toda a escova $(46 \%)(p=0,04)$. "Escovar os dentes" foi a resposta mais citada $(70,9 \%)$ em seus discursos sobre prevenção de cárie.

\section{Conclusão}

Mães primíparas e multíparas apresentaram, em geral, as mesmas características quanto ao conhecimento, ao acesso a informações e à busca por assistência odontológica. Houve diferença significativa entre os grupos apenas para a variável quantidade de dentifrício que se deve utilizar. Todavia, alguns aspectos como a etiologia multifatorial da cárie dentária, biofilme, uso de dentifrícios; bem como a busca por informações e serviços odontológicos em uma perspectiva de prevenção e promoção de saúde bucal ainda precisa ser trabalhado com estas mães; aspectos simples, mas que, devem ser praticados nos cuidados diários destas gestantes e puérperas.

Termos de indexação: Cárie dentária. Conhecimento. Gestantes.

\footnotetext{
${ }^{1}$ Universidade Estadual da Paraíba, Curso de Odontologia. Rua Juvêncio Arruda s/n., Campus Universitário, Bodocongó, 58429-600, Campina Grande, PB, Brasil. Correspondência para / Correspondence to: ACLT MASSONI. E-mail: <andrezatargino@gmail.com>

${ }^{2}$ Faculdades Integradas de Patos, Curso de Odontologia. Patos, PB, Brasil.

${ }^{3}$ Universidade Federal de Campina Grande, Curso de Odontologia. Patos, PB, Brasil.

${ }^{4}$ Universidade de Pernambuco, Faculdade de Odontologia. Camaragibe, PE, Brasil.
} 


\section{INTRODUCTION}

In the first days of life, parents act as active agent in the education and establishment of their children's habits and customs, making them aware of their needs'

In this context, women have a singular role in the family nucleus, caring for their health and that of their family members by means of actions that favor well-being, and consequently, improvement in the quality of life of individuals related to them in the domestic environment ${ }^{2}$. Interdisciplinary care of pregnant and puerperal women is essential in the quest for health, with the period of gestation being a favorable time for actions of this nature ${ }^{3}$. This period is important and favorable to the activities of prevention and health promotion of the mother and child, because the woman is more susceptible to changes and to processing information about her own health and that of her baby ${ }^{4-5}$.

Nevertheless, not all mothers have information with respect to care of her own oral health, which may reflect on the oral health of her baby, due to non adoption of the practices necessary for maintaining and providing adequate development of the stomatognathic system during early childhood. This occurs, not only due to negligence, but mainly because of lack of information and guidance during the prenatal period. In this sense, it is relevant to perform educational and preventive actions during follow-up of pregnancy, in addition to including participation of the dentist in multi-disciplinary care during the prenatal period, in order to ensure the success of these actions ${ }^{2,6-7}$.

In view of the above-mentioned considerations, the question arises: does the presence of one or more children before pregnancy or puerperium determine differences in the knowledge of mothers about aspect connected with oral health, such as understanding of one of the most prevalent diseases that affect the mouth namely dental caries?

In this context, the aim of this study was to make a comparative assessment of knowledge about dental caries among primiparous and multiparous women in a mediumsized city in the Seridó region of Rio Grande do Norte; in addition to data about their access to information and use of dental service during pregnancy.

\section{METHODS}

This study, developed in a Reference Maternity clinic for the region of Seridó do Rio Grande do Norte, is characterized as being cross-sectional, descriptive and quantitative $^{8}$, in which a structured form was used, which contained questions related to the number of children born alive; access to information; use made of dental services, and the topic of dental caries, including biofilm and basic oral hygiene care.

The faithfulness of replies was tested by the "face" validation method with $10 \%$ of the participants. In this method, the researcher asks the decision makers to explain, in their own words, what they understand about each question ${ }^{8}$.

The study population consisted of pregnant, puerperium, primiparous and multiparous women, aged between 12 and 45 years, who were receiving prenatal care during the period of data collection, and who agreed to participate in the research, by signing the Term of Free and Informed Consent, or by receiving this authorization from their guardians if they were minors.

To create the sample, the number of births and attendances of the pregnant women at the Maternity outpatient clinic during a month were considered, which comprised around 100 births and attendances. In order to determine the sample size the following could be considered: finite population of 100 , acceptable error of $5.0 \%$, level of confidence of $95 \%$, prevalence of $50.0 \%$ (for unknown value of the phenomenon) and calculation formula for finite populations. The sample size calculated was 80 pregnant and puerperal women; with $20 \%$ being added to compensate eventual losses; resulting in 96 participants selected by convenience ${ }^{8}$. A sample of 100 participants was established due to the facility of data computation and analysis.

Data collection was performed by two trained researchers. After data collection, the data were analyzed by descriptive and inferential statistics by means of the software SPSS, version 19.0 (Statistical Package for the Social Sciences, Chicago, USA, 2004). The following statistical tests were used: Pearson Chi-square and Exact Fisher tests, when there were no conditions for the use of the Chi-square test. The level of significance considered in the statistical tests was $5 \%$.

After consolidation of the information, the results were set out in Tables and the discourses were transcribed and analyzed in accordance with the pertinent literature.

Before being conducted, this study was submitted for appreciation of and authorization by the Ethics Committee on Research in Human Beings, of the Institution to which the research is linked, and obtained a favorable report (Protocol No. 0862/2010). The ethical principles 
proposed in the National Health Council Resolution 196/96 were complied with, and secrecy of the data with reference to the participants and their independence either to participate in the research, or not were guaranteed, as explained in the Term of Free and Informed Consent.

\section{RESULTS}

Association of the variables: access to information, seeking oral health services during pregnancy, knowledge about dental caries, biofilm and oral hygiene resources with regard to parity of the pregnant and puerperal women may be observed in Table 1.

The majority of participants $(70 \%)$ received information about oral health care $(p=0.24)$. However, only $42 \%$ sought dental attendance during pregnancy $(p=0.45)$, with the main reasons reported being caries, pain or edema in the region of some tooth $(57.1 \%)(p=0.42)$.

As regards understanding about dental caries, $80 \%$ of the interviewees considered it a disease $(p=0.80)$, $64 \%$ affirmed that is was communicable $(p=0.29)$ and $60 \%$ responded that it was due to inadequate tooth brushing $(p=0.37)$. When asked about dental biofilm,
$11 \%$ of the women researched associated it with bacteria on tooth surfaces $(p=0.36)$.

It was observed that $59 \%$ of the mothers considered the tooth brush with soft bristles and small head adequate $(p=0.83)$. However, most of the mothers $(46 \%)$ affirmed that the quantity of toothpaste must extend over the entire brush (46\%). This variable presented statistically significant difference $(p=0.04)$ among the groups analyzed. The pregnant and multiparous women considered the ideal quantity of dentifrice to use to be the amount that extended across the entire brush, whereas the majority of primiparous women related that the adequate amount of dentifrice was equivalent to the size of a single pea.

Distribution of the mothers according to the responses shown in their discourses, when asked about what was necessary to prevent dental caries, is presented din Table 2. By means of Analysis of Contet $^{9}$, the response "to brush the teeth" was observed to be the most cited $(70.94 \%)$. Some of the discourses reflected the manifestations of the interviewees:

"I think one should treat one's teeth well, brushing whenever one eats"

"Brush one's teeth after meals and use dental floss".

Table 1. Association between variables linked to oral health and parity of the interviewees, Rio Grande do Norte, Brazil (2013).

\begin{tabular}{|c|c|c|c|c|c|c|c|}
\hline \multirow{2}{*}{ Variables } & \multicolumn{7}{|c|}{ Parity } \\
\hline & $\mathrm{n}$ & $\%$ & $\mathrm{n}$ & $\%$ & $\mathrm{n}$ & $\%$ & $\mathrm{p}$-Value \\
\hline Yes & 63 & 63 & 7 & 7 & 70 & 70 & \multirow[t]{2}{*}{$P=0.24^{(1)}$} \\
\hline No & 29 & 29 & 1 & 1 & 30 & 30 & \\
\hline \multicolumn{8}{|l|}{ Did you seek dental care during pregnancy? } \\
\hline Yes & 38 & 38 & 4 & 4 & 42 & 42 & \multirow[t]{3}{*}{$P=0.45^{(1)}$} \\
\hline No & 54 & 54 & 4 & 4 & 58 & 58 & \\
\hline Total & 92 & 92 & 8 & 8 & 100 & 100 & \\
\hline \multicolumn{8}{|l|}{ Reason for seeking dental attendance } \\
\hline Total & 38 & 90.5 & 4 & 9.5 & 42 & 100.0 & \\
\hline \multicolumn{8}{|l|}{ Is dental caries a disease? } \\
\hline Yes & 74 & 74 & 6 & 6 & 80 & 80 & \multirow{3}{*}{$P=0.80(2)$} \\
\hline No & 16 & 16 & 2 & 2 & 18 & 18 & \\
\hline I don't know & 2 & 2 & 0 & 0 & 2 & 2 & \\
\hline Total & 92 & 92 & 8 & 8 & 100 & 100 & \\
\hline
\end{tabular}




\begin{tabular}{|c|c|c|c|c|c|c|c|}
\hline \multicolumn{8}{|l|}{ Is dental caries communicable? } \\
\hline Yes & 60 & 60 & 4 & 4 & 64 & 64 & \multirow{4}{*}{$P=0.29^{(2)}$} \\
\hline No & 24 & 24 & 4 & 4 & 28 & 28 & \\
\hline I don't know & 8 & 8 & 0 & 0 & 8 & 8 & \\
\hline Total & 92 & 92 & 8 & 8 & 100 & 100 & \\
\hline \multicolumn{8}{|l|}{ Why does caries appear? } \\
\hline We do not brush our teeth adequately & 60 & 60 & 4 & 4 & 64 & 64 & \multirow{5}{*}{$P=0.37^{(2)}$} \\
\hline Teeth have a tendency towards it & 6 & 6 & 0 & 0 & 6 & 6 & \\
\hline We consume excessive amount of sugar & 6 & 6 & 0 & 0 & 6 & 6 & \\
\hline The three affirmations are correct & 17 & 17 & 3 & 3 & 20 & 20 & \\
\hline I don't know & 3 & 3 & 1 & 1 & 4 & 4 & \\
\hline Total & 92 & 92 & 8 & 8 & 100 & 100 & \\
\hline \multicolumn{8}{|l|}{ What is dental biofilm? } \\
\hline Food remainders on one's teeth & 36 & 36 & 1 & 1 & 37 & 37 & \multirow{5}{*}{$P=0.36^{(2)}$} \\
\hline Bacteria on tooth surfaces & 9 & 9 & 2 & 2 & 11 & 11 & \\
\hline Yellow mass on tooth surfaces & 30 & 30 & 3 & 3 & 33 & 33 & \\
\hline I don't know & 17 & 17 & 2 & 2 & 19 & 19 & \\
\hline Total & 92 & 92 & 8 & 8 & 100 & 100 & \\
\hline \multicolumn{8}{|l|}{ A good brush is one that has: } \\
\hline Hard bristles and a large head & 34 & 34 & 3 & 3 & 37 & 37 & \multirow{3}{*}{$P=0.83^{(2)}$} \\
\hline Soft bristles and a small head & 54 & 54 & 5 & 5 & 59 & 59 & \\
\hline I don't know & 4 & 4 & 0 & 0 & 4 & 4 & \\
\hline Total & 92 & 92 & 8 & 8 & 100 & 100 & \\
\hline \multicolumn{8}{|l|}{ What is the adequate amount of toothpaste? } \\
\hline The size of a pea & 37 & 37 & 4 & 4 & 41 & 41 & \multirow{3}{*}{$P=0.04^{(2)}$} \\
\hline The amount that covers the entire brush & 45 & 45 & 1 & 1 & 46 & 46 & \\
\hline One that foams a great deal & 10 & 10 & 3 & 3 & 13 & 13 & \\
\hline Total & 92 & 92 & 8 & 8 & 100 & 100 & \\
\hline
\end{tabular}

Legend: (1) Exact Fischer Test; (2) Pearson Chi-Square test; *Significant association at the level of 5\%.

Table 2. Distribution of mothers according to the responses given to the question: What is necessary to prevent caries?" * Rio Grande do Norte, Brazil (2013).

\begin{tabular}{lcc}
\hline What is necessary to prevent caries?" * $^{*}$ & $\mathrm{n}$ \\
\hline Brush the teeth correctly (after meals, three times a day, before going to sleep). & 90 & 70.94 \\
Care with diet (diminish or stop eating sweets, avoid sugar) & 14 & 11.0 \\
Visit to Dentist & 13 & 10.2 \\
Use dental floss & 9 & 1.08 \\
I don't know & $\mathbf{1 2 7}$ \\
Total & $\mathbf{1 2 7}$ \\
\hline
\end{tabular}

Legend: *Considering that each interviewee could provide more than one answer

\section{DISCUSSION}

Women may be classified by parturition or the number of births. In the biological literature biological, the woman giving birth for the first time is denominated primiparous, and multiparous, in subsequent births. In this study, this demographic profile of the participants was evaluated, because the aim was to verify whether the presence of one or more children before the present gestation or puerperium would make a difference in the 
knowledge of these mothers about dental caries and to seeking dental care. The majority (92\%) were found to have other children. This result corroborates the data of an epidemiological study conducted in Australia, which evaluated the knowledge of pregnant women about oral health, and also observed a higher number of multiparous women ${ }^{10}$.

The majority of primiparous and multiparous mothers in this study affirmed having had access to information about oral health care, which differs from the results found in other studies, which showed that the majority of the participants informed that they had not received any information about the subject ${ }^{10-13}$. Therefore, this may be considered a relevant finding, since access to information favors the incorporation of new attitudes and behaviors, leading to pregnant women being active as regards the care required for oral health, and for the health of their children ${ }^{14}$.

Fewer than half of the interviewees sought dental care during pregnancy, corroborating the data from another study ${ }^{15}$. The pregnant woman must be attended whenever she spontaneously seeks assistance ${ }^{2}$. However, this makes it necessary to develop professional activities encouraging this demand, by providing more extensive explanations about the possibility of treatment, and the meaning of chronic conditions with regard to factors of risk to oral health during gestation.

Among the mothers investigated, a low number sought dental treatment, with the purpose of receiving information about the oral health of the child who was about to be born. From this perspective, it is important to reflect, or question whether this finding occurred as a results of the mothers already being informed about the subject; since the majority of the multiparous mothers did not seek information during the dental consultation; or whether this was due to the low perception of the importance of early care of the baby's oral hygiene. In general, the pregnant women related oral health to general health, but did not seek dental care during pregnancy ${ }^{16}$.

It was verified that the pregnant women recognized dental caries as an oral problem, and associated this problem especially with lack of hygiene ${ }^{17}$. In the present research, the interviewees considered dental caries a disease, and affirmed that this may be transmitted from person to person. This finding is relevant, because the mother is a key element in the chain of transmitting caries to the baby ${ }^{18}$, especially since the literature shows that one of the most effective means of caries prevention is the mother's education ${ }^{19}$. The mothers' awareness of caries disease is a factor favorable to the development of actions directed toward its control and prevention ${ }^{20}$.

As far as the etiologic factors of dental caries are concerned, it is important to point out that the present research endeavored to simplify the questions in order to make them more accessible to the interviewees. It is observed that the majority of the interviewees understood that inadequate tooth brushing favors the appearance of caries. However, only the minority of interviewees informed that the appearance of caries is associated with three etiologic factors. These data show that there is little understanding by the participants about the multifactorial nature of this disease. In another study, the minority of the interviewees also associated caries and multifactoriality ${ }^{21}$. Tooth brushing is fundamental for caries prevention, because it prevents the demineralization process, and disorganizes the biofilm. However, brushing alone is not sufficient to present dental caries, since it is considered a disease with multi factorial etiology, favored by aspects such as a carcinogenic diet, host susceptibility and exposure to fluorides ${ }^{22}$

Dental biofilm is one of the main factors that cause caries and periodontal disease, as the adhesion of perexistent microorganisms to the tooth crown and gingival region is necessary for its formation ${ }^{23}$. Nevertheless, the majority of the participants in this study considered biofilm to be "remainders of food on the tooth surfaces", and only a minority of the mothers associated it with microorganisms on the tooth surfaces. This demonstrates the demand for information about the topic, in order to elucidate the role of this factor as determinant in the development of dental caries and periodontal disease.

When verifying the knowledge of the interviewees about which of the oral hygiene resources was the appropriate tooth brush, the majority of them pointed out the type with the small head and soft bristles. The brush with soft bristles is less aggressive, and the small head helps to reach the places that are difficult to access ${ }^{21}$. These results are in agreement with the literature, however, it could be verified that there were still a significant number of participants that consider the ideal toothbrush to be the one with a large head and hard bristles. This point must be worked on when providing pregnant and parturient women with guidance, because this is an etiologic factor in injuries to dental and gingival tissues ${ }^{24}$.

When questioned about the quantity of dentifrice to be used in each tooth brushing session, 
a significant difference was verified between the two groups investigated $(p=0.04)$. The multiparous mothers reported a quantity that extended across the entire brush to be adequate, which is indeed inadequate. Considering that not only is a quantity equivalent to the size of one pea sufficient to perform oral hygiene ${ }^{25}$, but there is the risk of chronic toxicity as a result of fluoride ingestion when very young children are exposed to large quantities of fluoridated dentifrice during tooth brushing ${ }^{26}$. These findings demand reflection about the origin of the information. The question arises about whether there is a connection with the vehicles of communication by means of advertising. The concept of primiparous mothers is more suited to the Literature, since they correctly pointed out that the ideal quantity of dentifrice is equivalent to the size of one pea.

From this perspective it is necessary to arouse the attention of professionals who work with pregnant and pueperal women, whether they are primiparous or multiparous, about the need to rethink oral health promotion strategies during prenatal follow-up, since this is a very receptive group, and one that is essential for establishing daily habits that lead to health right from the time of childhood.

\section{REFERENCES}

1. Massoni ACLT, Ferreira JMS, Silva FDSCM, Carvalho LFPC, Duarte RC. Conhecimento das gestantes sobre a saúde bucal dos bebês. Rev Bras Cien Saúde. 2009;13(1):41-7.

2. Reis DM, Pita DR, Ferreira HMB, Jesus MCP de, Moraes MEL de, Soares MG. Educação em saúde como estratégia de promoção de saúde bucal em gestantes. Ciên Saúde Coletiva. 2010;15(1):269-76. doi: 10.1590/S1413-81232010000100032

3. Moura LFAD, Lira DMMP, Moura MS, Barros, SSLV, Lopes TSP, Leopoldino VD, et al. Apresentação do programa preventivo para gestantes e bebês. J Bras Odontopediatr Odontol Bebê. 2001;4(17):10-4.

4. Codato LAB, Nakama L, Melchior R. Percepções de gestantes sobre atenção odontológica durante a gravidez. Ciênc Saúde Colet. 2008;13(3):1075-80. doi: 10.1590/S141381232008000300030

5. Nogueira LT, Valsecki-Júnior A, Martins CR, Rosell FL, Silva SRC. Retardo na procura do tratamento odontológico e percepção da saúde bucal em mulheres grávidas. Odontol Clín-Cient. 2012;11(2):127-31

6. Melo FGC, Cavalcanti AL, Fontes LBC, Granville-Garcia AF, Cavalcanti SDALB. Perda precoce de molares permanentes e fatores associados em escolares de 9,12 e 15 anos da rede

\section{CONCLUSION}

Primiparous and multiparous mothers, in general, presented the same characteristics as regards knowledge, access to information, and seeking dental care. There was significant difference between the groups only for the variable quantity of dentifrice that must be used. Nevertheless, some aspects such as the multifactorial etiology of dental caries, biofilm, use of dentifrices, and those of seeking information and dental services from a perspective of oral health prevention and promotion still need to be worked on with these mothers. They are simple aspects, but ones that must be practiced in the daily care of these pregnant and pueperal women.

\section{Collaborators}

ACLT MASSONI guided all the stages of the study, cooperated with data analysis and interpretation and participated in writing the manuscript. RB PEREIRA participated in the collection, analysis and interpretation of data, and in writing the article. DRM NÓBREGA, LED COSTA, JMF ALENCAR and A ROSENBLATT participated in the analysis and interpretation of data, and in writing the article.

pública municipal de Campina Grande, Estado da Paraíba, Brasil. Acta Sci Health Sci. 2011;33(1):99-105.

7. Granville-Garcia AF, Leite AF, Smith LEA, Campos RVS, Menezes VA. Conhecimento de gestantes sobre saúde bucal no município de Caruaru - PE. Rev Odontol UNESP. 2007;36(3):243-9.

8. Antunes JLF, Peres MA. Fundamentos de Odontologia: epidemiologia da saúde bucal. Rio de Janeiro: Guanabara Koogan; 2006.

9. Minayo MCS. O desafio do conhecimento: pesquisa qualitativa em saúde. 9a ed. São Paulo: Hucitec; 2002.

10. George A, Johnson M, Blinkhorn A, Ajwani S, Bhole S, Yeo $A E$. The oral health status, practices and knowledge of pregnant women in south-western Sydney. Aust Dent J. 2013;58(1):2633. doi: 10.1111/adj.12024

11. Cruz AAM, Gadelha CGF, Cavalcanti AL, Medeiros PFV. Percepção materna sobre a higiene bucal de bebês. Pesq Bras Odontoped Clin Integr. 2004;4(3):185-9.

12. Günther K, Tovo MF, Feldens CA. Avaliação dos conhecimentos sobre saúde bucal referidos por parturientes do Hospital Luterano-ULBRA. Stomatos. 2005;11(20):5-12.

13. Scavuzzi AIF, Nogueira PM, Laporte ME, Alves AC. Avaliação dos conhecimentos e práticas em saúde bucal de gestantes atendidas no setor público e privado, em Feira de Santana, Bahia, Brasil. Pesq Bras Odontoped Clin Integr. 2008;8(1):39-45. 
14. Garbin CAS, Sumida DH, Santos RR, Chehoud KA, Moimaz SAS. Saúde coletiva: promoção de saúde bucal na gravidez. Rev Odontol UNESP. 2011;40(4):161-5.

15. Melo JM, Brandão EHS, Dutra SMV, Iwazawa AT, Albuquerque RS. Conhecendo a captação de informações de mães sobre cuidados com o bebê na estratégia Saúde da Família. Texto \& contexto Enferm. 2007;16(2):208-6. doi: 10.1590/S010407072007000200010

16. Medeiros UV, Zevallos EFP, Rosiangela K. Promoção da saúde bucal da gestante: garantia de sucesso no futuro. Rev Cient CRO-RJ. 2000;2:47-57.

17. Martins RFO, Martins ZIO. O que as gestantes sabem sobre cárie: uma avaliação dos conhecimentos de primigestas e multigestas quanto a própria saúde bucal. Rev ABO Nac. 2002;10(5):278-84.

18. Böncker $M$, Ardenghi TM, Trindade CP, Cury P. Transmissão vertical de Streptococcusmutanse suas implicações. J Bras Odontopediatr Odontol Bebê. 2004;7(37):297-303.

19. Feitosa C. Os fatores psicológicos e sociais relacionados a cárie precoce na infância. J Bras Odontopediatr Odontol Bebê. 2001;4(18):143-7.

20. Hana LMO, Nogueira AJS, Ronda VYS. Percepção das gestantes sobre a atenção odontológica precoce nos bebês. RGO - Rev Gaúch Odontol. 2007;55(3):271-4.
21. Massoni ACLT, Paulo SF, Forte FDS, Freitas CHSM, Sampaio FC. Saúde bucal infantil: Conhecimento e interesse de pais e responsáveis. Pesq Bras Odontop Clin Integr. 2010;10(2):257-64.

22. Macedo CR. Cuidados gerais e higiene oral para prevenção de cáries em crianças. Diagn tratamento. 2010;15(4):191-3.

23. Figueiredo MC, Faustino-Silva DD. Efetividade de dedeira de gaze comparada à escova dental convencional no controle do biofilme dentário em bebês. Conscientiae Saúde. 2008;7(3):357-66.

24. Barbosa e Silva E, Peruchi CMS, Santos-Pinto L, Sampaio JEC. Avaliação morfológica do arredondamento das cerdas de escovas dentárias importadas comercializadas no mercado nacional. Robrac. 2002;11(32):58-63.

25. Campos L, Bottan ER, Birolo JB, Silveira EG, Schmitt BHE. Conhecimento de mães de diferentes classes sociais sobre saúde bucal no município de Cocal do Sul (SC). Rev Sul-Bras Odontol. 2010;7(3):287-95.

26. Martins CC, Pinheiro NR, Paiva SM. Perfil de crianças portadoras de fluorose dentária quanto às diversas formas de acesso ao flúor. J Bras Odontopediatr Odontol Bebê. 2002;5(27):396-402.

Received on: 15/10/2013

Final version resubmitted on: 30/10/2013

Approved on: 24/6/2014 
